Research Article

\title{
AMINO ACID STATUS OF BOVINE MILK UNDER SEASONAL VARIATION AROUND SINGRAULI DISTRICT
}

\author{
RAJESH K. PATEL ${ }^{a}$, P. K. SINGH ${ }^{a}$, RAJESH PANDEYb, BABBULAL PATEL ${ }^{a}$, SANDEEP MISHRA ${ }^{a}$
}

aDepartment of Chemistry, SGS Govt. PG College, Sidhi, MP, India, 'Department of Biochemistry, APS University, Rewa, MP, India Email: rajeshkumarpatel410@gmail.com

Received: 19 Mar 2021 Revised and Accepted: 10 Jun 2021

\section{ABSTRACT}

Objective: The present work deals with the concerned study to determine the influence of variable season on amino acid evaluation from 90 bovine milk collected (March 2018 to February 2019) samples belongs to four tehsils of Singrauli district.

Methods: An aliquot of hydrolysate of collected bovine milk samples were injected into the column (Shim-pack ISC-07/S1504 Na) of the higher performance liquid chromatography-based amino acid analyzer.

Results: Most abundant amino acids were glutamic acid followed by proline and leucine. Average amino acid content comparison, results, in the rainy season, maximum amino acid content was in Deosar and minimum in Singrauli, In winter amino acid is higher in Waidhan and minimum in Deosar and maximum amino acid content was recorded intended for Waidhan and minimum for Deosar in summer. Concentration of amino acid in cow milk was found to be in order of glycine $<$ histidine $<$ alanine $<$ methionine $<$ isoleucine $<$ phenylalanine $<$ threonine $<$ tyrosine $<$ serine $<$ lysine $<$ valine and aspartic acid<arginine<leucine<proline $<$ glutamic acid. Amino acid status in buffalo milk sample was found in order Glycine $<$ histidine $<$ methionine $<$ alanine $<$ phenylalanine $<$ isoleucine $<$ threonine $<$ arginine $<$ tyrosine $<$ serine $\quad$ and $\quad$ lysine $<$ aspartic acid $<$ valine $<$ leucine $<$ proline $<$ glutamic acid. All the amino acids are evaluated as per the mean $(n=6)$ mean \pm SD.

Conclusion: It is concluded that cow and buffalo milk samples contained all the amino acids but differed in the contents of certain amino acids. Such variation is purely biological and genetic and is intended for the nourishment of the young. The current investigation would be valuable for the dairy processing industries to formulate nutritionally improved milk-based functional products for a vulnerable segment of the population.

Keywords: Amino acid, High-performance liquid chromatography, Bovine milk, Singrauli

(c) 2021 The Authors. Published by Innovare Academic Sciences Pvt Ltd. This is an open access article under the CC BY license (http://creativecommons.org/licenses/by/4.0/) DOI: http://dx.doi.org/10.22159/ijcr.2021v5i3.170. Journal homepage: https://ijcr.info/index.php/journal

\section{INTRODUCTION}

Milk is one of the most nutritionally complete foods. Bovine milk has long been the prime milk source for human consumption. Milk contains tremendous macro and micronutrients and therefore can play a significant role in serving individuals to meet their nutritional requirements. Among milk components, proteins are the most important constituents of the human diet contributing important nutritional, biological, and functional properties.

Milk is nearly an immaculate natural food consumed comprehensively around the globe for all phases of life [1]. Other than the nutrition some specific milk proteins take part in the early development of immune response and non-immunological defense [2]. Since recent years the consumption of milk and milk products such as cheese, yogurt, and milk powder has increased as it plays a vital role in human nutrition [3]. Regular milk consumption has been widely recommended as bovine milk contains a variety of most essential nutrients which are critical to maintaining the healthy life of each individual including human [4].

In human nutrition, the amino acid profile of caseins and whey proteins occupies a unique position. These proteins are ranked as quality proteins with the highest biological value, good digestibility (98\%), rapid absorption, and utilization in the body. Specifically, casein is an incredibly efficient nutrient supply owing to its providing a sustained and slow release of amino acids into the bloodstream [5]. Branched-chain amino acids (BCAAs) present in the highest concentration in milk proteins are important for the maintenance of tissue growth, repair, and prevention of catabolic actions during exercise. Similarly, the amino acid cysteine enhances glutathione levels, exhibits strong antioxidant properties, and assists the body in combating various diseases [5].

In addition, milk proteins are recognized for their applicability in sports nutrition, baked goods, salad dressings, emulsifiers, infant formulas, and medical nutritional formulas. Milk plays a vital role in building a healthy society and can be used as a vehicle for rural development. Milk of various species differs quantitatively and qualitatively according to constituents. Buffalo and cow are the top milk-producing animals in India that can contribute $62 \%$ and $34 \%$ milk production respectively [6]. Therefore, present research work was carried out on amino acid profiling of bovine milk (cow and buffalo).

\section{MATERIALS AND METHODS}

Study area

Present study areas include four different tahsils (Chitrangi, Waidhan, Devsor, and Singrauli) of Singrauli district of Madhya Pradesh, India which covers a region comprising of the eastern part of the Sidhi district also. Singrauli is fast emerging as an energy hub of India, especially for electric power and coal, and therefore locally it is also called Urjanchal. Energy-generating industries in the city are like Singrauli Super Power Plant (SSPP), Vindhyanchal Super Thermal Power Plant (VSTPP), Northen Coal Limited (NCL), etc.

The study area is well known for their higher pollutant especially those which directly release through power generation Industries and was assessed for heavy metal contamination in vegetables, fruits, etc but not yet explored for milk contamination. 




\section{Collection of milk samples}

Ninety fresh samples of buffalo and cow (45 samples of each species) were collected in sterile glass bottles from the Dairy Farm and local vendors of four different tehsils of Singrauli district. These samples were labeled, ice-packed, and transported to the laboratory. All milk samples were then placed in the refrigerator at $4{ }^{\circ} \mathrm{C}$ for further analysis.

\section{Amino acid profiling}

Sample preparation was done followed by standard methods with some modification [7]. $5 \mathrm{~g}$ of samples were hydrolyzed with $6 \mathrm{~N} \mathrm{HCl}$ in an electric oven at $110 \pm 1{ }^{\circ} \mathrm{C}$ for $24 \mathrm{hr}$. After hydrolysis, the sample hydrolysate was made free of excess $\mathrm{HCl}$ by the repeated evaporation of the hydrolysate under vacuum over $\mathrm{NaOH}$ pellets. Finally, $5 \mathrm{ml}$ water was added to dry samples and the process of evacuation repeated twice for removal of acid. The dried residues were then dissolved in a known quantity of $0.02 \mathrm{~N}$ sodium acetate buffer ( $\mathrm{pH} 2.20$ ), were decolorized by adding a pinch of activated charcoal, and then filtered through Whatman 42 filter paper to obtain a clean solution of the hydrolysate. An aliquot of hydrolysate was injected into the column (Shim-pack ISC-07/S1504 Na) of the higher performance liquid chromatography-based amino acid analyzer for profiling of amino acids.

\section{RESULTS AND DISCUSSION}

Food safety of milk and dairy products is a prerequisite for consumption, which must be free from physical, biological, and chemical contamination. Chemical contamination of heavy metals is generally derived from the environment such as from water, grass, and feed additives. In the present investigation, the established thermal power plants consume a large amount of coal to generate electricity. Due to this coal combustion, a significant quantity and variety of trace elements, some of them potentially toxic, is transferred to the nearby location through diverse pathways [8,9].

In milk, both essential and non-essential amino acid content was determined in cow and buffalo milk samples collected from a tehsil of Singrauli and the average concentration of individual amino acid was presented graphically in fig. 1. It was observed that the concentration of most of the amino acid was high in cow milk as compared to buffalo milk. Amount of glutamic acid $(22.70 \pm 0.17 \mathrm{~g} / 100 \mathrm{~g})$ was maximum in both cow $(22.70 \pm 0.17 \mathrm{~g} / 100 \mathrm{~g})$ and buffalo $(20.73 \pm 0.21 \mathrm{~g} / 100 \mathrm{~g})$ milk followed by a proline $(12.77 \pm 0.12 \mathrm{~g} / 100 \mathrm{~g}$ in cow and $10.70 \pm 0.10 \mathrm{~g} / 100 \mathrm{~g}$ in buffalo) while glycine was present in a minimum concentration in both cow $(2.03 \pm 0.06 \mathrm{~g} / 100 \mathrm{~g})$ and buffalo $(1.49 \pm 0.01 \mathrm{~g} / 100 \mathrm{~g})$. The contamination in milk is considered as one of the main dangerous aspects within the last few years. Chemical residues which could contaminate milk and milk products include environmental and anthropological factors [10].

Status of amino acid in cow milk was found to be in order of Glycine<histidine $<$ alanine $<$ methionine $<$ isoleucine $<$ phenylalanine $<$ threonine $<$ tyrosine $<$ serine $<$ lysine $<$ valine and aspartic acid $<$ arginine $<$ leucine $<$ proline $<$ glutamic acid. Conc. of amino acid in buffalo milk sample was found in order Glycine $<$ histidine $<$ methionine $<$ alanine $<$ phenylalanine $<$ isoleucine $<$ threonine $<$ arginine $<$ tyrosine $<$ serine and lysine $<$ aspartic acid $<$ valine $<$ leucine $<$ proline $<$ glutamic acid. Milk contamination issues are an extreme concern since milk and milk products have a very special position in the diet of infants, children, and the elderly for whom these are considered as perfect natural food [11]. Monitoring of bovine milk samples from different places of the Bundelkhand region in India explores the status of pesticide residues [11, 12]. 


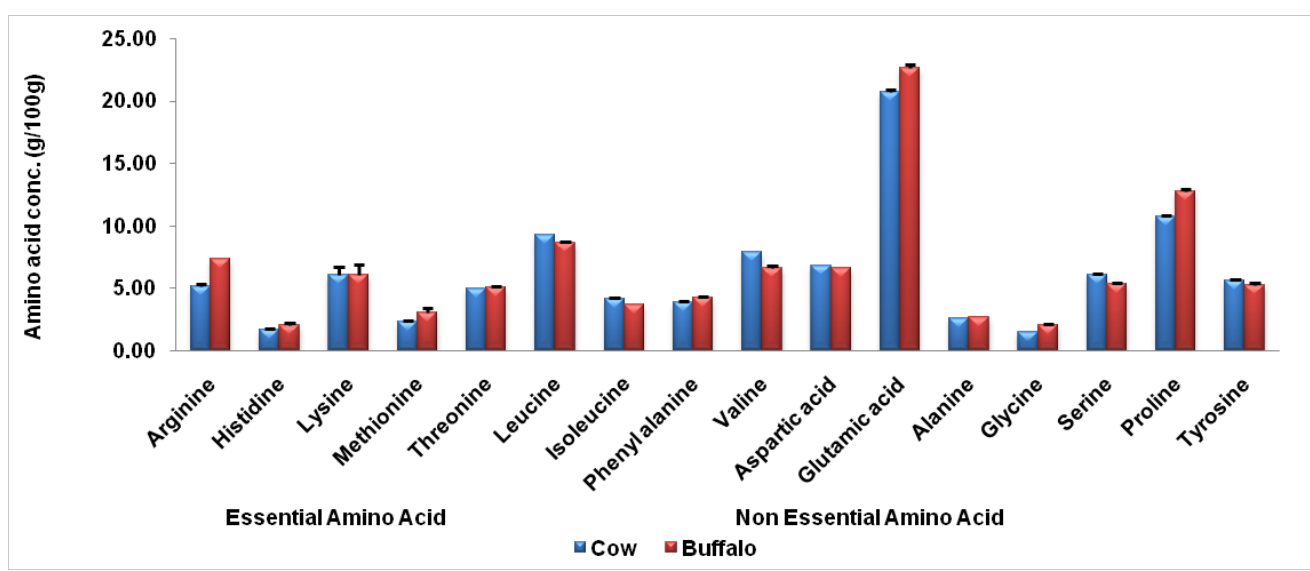

Fig. 1: Average concentration of amino acids in bovine milk samples collected from a different tehsil of Singrauli district during a different season. Values were expressed in $(n=6)$ mean $\pm S D$

The result of the effect of seasonal variation on the amount of amino acid in bovine milk revealed that concentration of histidine, leucine, isoleucine, phenylalanine, aspartic acid, alanine, glycine, and serine in buffalo milk is almost the same during rainy, winter, and summer season (table 1). The concentration of arginine, lycine, methionine, and threonine is more in the winter season i. e $5.32 \mathrm{~g} / 100 \mathrm{~g}, 6.5 \mathrm{~g} / 100 \mathrm{~g}, 2.42 \mathrm{~g} / 100 \mathrm{~g}$, and $5 \mathrm{~g} / 100 \mathrm{~g}$ respectively while was least in summer $5 \mathrm{~g} / 100 \mathrm{~g}, 5.3 \mathrm{~g} / 100 \mathrm{~g}, 2.2 \mathrm{~g} / 100 \mathrm{~g}$ and $4.85 \mathrm{~g} / 100 \mathrm{~g}$ respectively. The concentration of glutamic acid $(20.8$ $\mathrm{g} / 100 \mathrm{~g})$, proline $(10.8 \mathrm{~g} / 100 \mathrm{~g})$, and tyrosine $(5.7 \mathrm{~g} / 100 \mathrm{~g})$ were found to be maximum during the rainy season while the concentration of valine $(7.9 \mathrm{~g} / 100 \mathrm{~g})$ was the same during both rainy and winter season. The concentration of valine $(7.84 \mathrm{~g} / 100 \mathrm{~g})$ and glutamic acid $(20.5 \mathrm{~g} / 100 \mathrm{~g})$ was found to be minimum in the summer season while the concentration of proline $(10.6 \mathrm{~g} / 100 \mathrm{~g})$ and tyrosine $(5.4 \mathrm{~g} / 100 \mathrm{~g})$ was minimum in the winter season. In parts of Singrauli, fly ash lies in piles five feet thick, consists of fine particles of Ca, S, Mg, and Si along with toxic elements like $\mathrm{Hg}$, $\mathrm{Pb}$, As, $\mathrm{Se}$, and $\mathrm{Cd}[10]$. These heavy metals can leach into groundwater and soils, causes acid rain, and affect human health through inhalation and through dietary involvement, mostly obtain the dietary product of animals.

Table 1: Effect of seasonal variation on concentration of amino acid in buffalo milk samples collected from different tehsil of Singrauli district, values were expressed in $(n=6)$ mean $\pm S D$

\begin{tabular}{llll}
\hline Amino acids & Rainy & Winter & Summer \\
\hline Arginine & $5.2 \pm 0.32$ & $5.32 \pm 0.17$ & $5 \pm 0.28$ \\
Histidine & $1.7 \pm 0.18$ & $1.7 \pm 0.23$ & $6.5 \pm 0.15$ \\
Lysine & $6.4 \pm 0.21$ & $2.42 \pm 0.24$ & $5.3 \pm 0.14$ \\
Methionine & $2.3 \pm 0.12$ & $5 \pm 0.18$ & $2.28 \pm 0.21$ \\
Threonine & $4.9 \pm 0.24$ & $9.25 \pm 0.4$ & $4.85 \pm 0.25$ \\
Leucine & $9.2 \pm 0.12$ & $4.2 \pm 0.1$ & $9.2 \pm 0.34$ \\
Isoleucine & $4.1 \pm 0.27$ & $3.8 \pm 0.28$ & $7.12 \pm 0.2$ \\
Phenyl alanine & $3.9 \pm 0.36$ & $6.9 \pm 0.51$ & $3.9 \pm 0.14$ \\
Valine & $7.9 \pm 0.62$ & $20.8 \pm 0.29$ & $7.84 \pm 0.23$ \\
Aspartic acid & $6.8 \pm 0.49$ & $2.6 \pm 0.1$ & $6.8 \pm 0.4$ \\
Glutamic acid & $20.9 \pm 0.57$ & $1.48 \pm 0.13$ \\
Alanine & $2.6 \pm 0.12$ & $6 \pm 0.32$ & $20.5 \pm 0.44$ \\
Glycine & $1.5 \pm 0.09$ & $10.6 \pm 0.37$ \\
Serine & $6.1 \pm 0.43$ & $5.4 \pm 0.26$ \\
Proline & $10.8 \pm 0.49$ & & $2.6 \pm 0.22$ \\
Tyrosine & $5.7 \pm 0.35$ & & $1.5 \pm 0.15$ \\
\hline
\end{tabular}

Tyrosine

Values were expressed in $(n=6)$ mean \pm SD.

In cow milk, most of the amino acids reported their maximum concentration in the winter season (table 2). The concentration of arginine $(7.3 \mathrm{~g} / 100 \mathrm{~g})$, aspartic acid $(6.6 \mathrm{~g} / 100 \mathrm{~g})$, and glycine $(2.0 \mathrm{~g} / 100 \mathrm{~g})$ were found to be the same during the rainy and winter season while the status of histidine $(2.0 \mathrm{~g} / 100 \mathrm{~g})$ and leucine $(8.68 \mathrm{~g} / 100 \mathrm{~g})$ was same during winter and summer season. The concentration of isoleucine $(3.7 \mathrm{~g} / 100 \mathrm{~g})$, glutamic acid (22.6g/100g), glycine $(2.0 \mathrm{~g} / 100 \mathrm{~g})$, serine $(5.3 \mathrm{~g} / 100 \mathrm{~g})$, proline $(12.7 \mathrm{~g} / 100 \mathrm{~g})$, and tyrosine $(5.2 \mathrm{~g} / 100 \mathrm{~g})$ was found to be same during rainy and summer season while there was a slight variation in concentration of the rest of amino acid in rainy, winter and summer season.

Table 2: Effect of seasonal variation on the concentration of amino acid in cow milk samples collected from a different tehsil of Singrauli district, values were expressed in $(n=6)$ mean $\pm S D$

\begin{tabular}{llll}
\hline Amino acids & Rainy & Winter & Summer \\
\hline Arginine & $7.3 \pm 0.3$ & $7.3 \pm 0.18$ & $7.28 \pm 0.21$ \\
Histidine & $2.2 \pm 0.1$ & $2 \pm 0.2$ & $2 \pm 0.3$ \\
Lysine & $5.2 \pm 0.25$ & $6.7 \pm 0.3$ & $6.4 \pm 0.2$ \\
Methionine & $2.8 \pm 0.15$ & $3.5 \pm 0.24$ & $2.82 \pm 0.14$ \\
Threonine & $5.1 \pm 0.2$ & $4.94 \pm 0.29$ & $5.0 \pm 0.32$ \\
\hline
\end{tabular}




\begin{tabular}{llll}
\hline Leucine & $8.6 \pm 0.39$ & $8.68 \pm 0.21$ & $8.68 \pm 0.1$ \\
Isoleucine & $3.7 \pm 0.12$ & $3.67 \pm 0.31$ & $3.7 \pm 0.23$ \\
Phenyl alanine & $4.2 \pm 0.1$ & $4.3 \pm 0.42$ & $4.14 \pm 0.17$ \\
Valine & $6.5 \pm 0.3$ & $6.8 \pm 0.27$ & $6.42 \pm 0.28$ \\
Aspartic acid & $6.6 \pm 0.45$ & $6.6 \pm 0.23$ & $6.5 \pm 0.1$ \\
Glutamic acid & $22.6 \pm 0.51$ & $22.9 \pm 0.47$ & $22.5 \pm 0.32$ \\
Alanine & $2.7 \pm 0.15$ & $2.6 \pm 0.17$ & $2.63 \pm 0.07$ \\
Glycine & $2 \pm 0.1$ & $2 \pm 0.12$ & $2.1 \pm 0.19$ \\
Serine & $5.3 \pm 0.41$ & $5.4 \pm 0.22$ & $5.3 \pm 0.38$ \\
Proline & $12.7 \pm 0.6$ & $12.9 \pm 0.42$ & $12.7 \pm 0.25$ \\
Tyrosine & $5.2 \pm 0.27$ & $5.4 \pm 0.38$ & $5.2 \pm 0.42$ \\
\hline
\end{tabular}

Values were expressed in $(n=6)$ mean \pm SD.

Results of the present study revealed that glutamic acid amino acid was the present in greatest concentration in both cow and buffalo milk followed by proline and leucine. This conclusion was consistent with previous also studies $[13,14]$. Glutamic acid to be one of the most abundant amino acids in bovine milk samples [15]. Leucine plays a distinct role in protein metabolism and the translation initiation pathway of muscle protein synthesis. It is also involved in reversible phosphorylation of proteins that control mRNA binding to the 40S ribosomal subunit [16].

\section{CONCLUSION}

It is concluded that cow and buffalo milk samples contained all the amino acids but differed in the contents of certain amino acids. Such variation is purely biological and genetic and is intended for the nourishment of the young. The current investigation would be valuable for the dairy processing industries to formulate nutritionally improved milk-based functional products for a vulnerable segment of the population.

\section{ACKNOWLEDGEMENT}

Authors are thankful to the dairy owner and local milk vendors for participating in this study and providing the samples.

\section{FUNDING}

Nil

\section{AUTHORS CONTRIBUTIONS}

All the authors have contributed equally.

\section{CONFLICT OF INTERESTS}

\section{Declared none}

\section{REFERENCES}

1. Mathur BN, Thompkinson D, Bikhi L. Milk the nectar for living beings. Indian Dairyman 2000;52:11-20.

2. Haug A, Høstmark AT, Harstad OM. Bovine milk in human nutrition a review. Lipids Health Disease 2007;6:25.

3. Khalil HM, Seliem AF. Determination of heavy metals (Pb, Cd) and some trace elements inmilk and milk products collected from Najran region in KSA. Life Sci J 2013;2:648.

4. Arianejad M, Alizadeh M, Bahrami A, Arefhoseini SR. Levels of some heavy metals in raw cow milk from selected milk production sites in Iran: Is There any Health Concern. Health Promotion Perspectives 2015;5:176.

5. Schaafsma G. The protein digestibility corrected amino acid score. J Nutr 2007;130:1865-7.

6. Han BZ, Meng Y, Li M, Yang YX, Ren FZ, Zeng QK, Nout MR. A survey on the microbiological and chemical composition of buffalo milk in China. Food Controlled 2007;18:742-6.

7. Ishaq Z, Ishaq N, Ishaq I, Hussain A, Sajid MW. Screening of organochlorine pesticide residues in milk collected from sahiwal region. Inter J Sci Eng Res 2017;8:955-68.

8. Goodarzi F, Huggins FE, Sanei H. Assessment of elements, speciation of As, Cr, Ni and emitted Hg for a canadian power plant burning bituminous coal. Inter J Coal Geol 2008;74:1-12.

9. Reddy MS, Basha S, Joshi HV, Jha B. Evaluation of the emission characteristics of trace metals from coal and fuel oil fired power plants and their fate during combustion. J Hazardous Materials 2005;123:242-9.

10. Malhat F, Hagag M, Saber A, Fayz AE. Contamination of cow's milk by heavy metal in Egypt. Bull Environ Contamination Toxicol 2012;88:611-3.

11. Nag SK, Raikwar MK. Organochlorine pesticide residues in bovine milk. Bull Environ Contamination Toxicol 2008;80:5-9.

12. Nag SK, Raikwar MK. Persistent organochlorine pesticide residues in animal feed. Environ Monitoring Assessment 2011;174:327-35.

13. Sarwar G, Botting HG, Davis TA, Darling P, Pencharz PB. Free amino acids in milks of human subjects, other primates and non-primates. Br J Nutr 1998;79:129-31.

14. Lindmark Mansson H, Fonden R, Pettersson HE. Composition of swedish dairy milk. Inter Dairy J 2003;13:409-25.

15. Roucher VF, Desnots E, Nael C, Agnoux AM, Alexandre Gouabau MC, Darmaun D, et al. Use of UPLC-ESI-MS/MS to quantitated free amino acid concentrations in micro samples of mammalian milk. Springer Plus 2003;622:1.

16. Anthony JC, Anthony TG, Kimball SR, Jefferson LS. Signaling pathways involved in translational control of protein synthesis in skeletal muscle by leucine. J Nutr 2001;131:856-60. 